\title{
Influence of various fermentation variables on exo-glucanase production in Cellulomonas flavigena
}

\author{
Muhammad Ibrahim Rajoka \\ National Institute for Biotechnology and Genetic Engineering \\ (NIBGE), Faisalabad, Pakistan \\ Tel: 9241651475 \\ Fax: 9241651472 \\ E-mail:mirajoka@nibge.org
}

\begin{abstract}
Financial support: Pakistan Atomic Energy Commission, Islamabad and in part by a grant made by the United States Agency for International
\end{abstract} Development under PSTC proposal 6-163, USAID grant no. 9365542-G00-89-42-00.

Keywords: Carbohydrates, cellobiohydrolase, Cellulomonas flavigena, exo-glucanase, enthalpy, entropy, fermentation, induction.

The influence of carbon and nitrogen sources on the production of exo-glucanase was investigated. The enzyme production was variable according to the carbon or nitrogen source used. Levels of $\beta$ cellobiohydrolase $(\mathrm{CBH})$ were minimal in the presence of even low concentrations of glucose. Enzyme production was stimulated by other carbohydrates and thus is subject to carbon source control by easily metabolizable sugars. In Dubos medium, on cellobiose, the cellobiohydrolase titres were 2-to 110-fold higher with cells growing on monomeric sugars and 2.7 times higher than cells growing on other disaccharides. aCellulose was the most effective inducer of $\beta$ cellobiohydrlase and filter paperase (FPase) activities, followed by kallar grass straw. Exogenously supplied glucose inhibited the synthesis of the enzyme in cultures of Cellulomonas flavigena. Nitrates were the best nitrogen sources and supported greater cell mass, cellobiohydrolase and FPase production. During growth on $\alpha$-cellulose containing 8 -fold sodium nitrate concentration, maximum volumetric productivities $\left(Q_{\mathrm{p}}\right)$ of $\beta$-cellobiohydrolase and FPase were 87.5 and 79.5 $\mathrm{IU} / \mathrm{l}$./h respectively and are significantly higher than the values reported for some other potent fungi and bacteria.

Cellulases and xylanases are implicated in baked foods, fruit processing, cloth cleaning, preparation of dehydrated vegetables and food products, preparation of essential oils, flavours, pulp and paper production, starch processing, preparation of botanical extracts, jams, baby foods, juices, degumming coffee extracts, improved oil recovery, waste treatment, textile refining and preparation of feed for farm animals (Kubicek et al. 1993; Hoshino et al. 1997; Lynd et el. 2002).

Cellulase production has attracted a world-wide attention due to the possibility of using this enzyme complex for conversion of abundantly available renewable lignocellulosiclignocellulosic (LC) biomass for production of carbohydrates for numerous industrial applications including bioethanol (Gadgil et al. 1995; Hayward et al. 2000). Economical production of cellulases is key for feasible bioethanol production from LC biomass using cellulase-based processes. Different fungi and bacteria have been used for production of cellulases and xylanases using different substrates (Bahkali, 1996; Magnelli and Forchiassin, 1999; Shin et al. 2000; Lynd et al. 2002). Previously we produced cellulases following growth of $C$. biazotea on different substrates produced on saline lands namely Leptochloa fusca (kallar grass) straw, Panicum maximum, Sesbania aculeata compared with bagasse straw, and wheat straw and found that kallar grass was superior to other substrates for supporting synthesis of cellulases (Rajoka and Malik, 1997). Cellulase system of C. flavigena which produced high activities of cellulases and xylanases during growth on kallar grass showed end-product inhibition-resistance and thermal stability at room temperature of $25^{\circ} \mathrm{C}$ (Rajoka, 1990). These enzyme characteristics prompted to further investigate the production potential of FPase, cellobiohydrolase or exoglucanase (EC 3.2.1.91) as it measures the complete cellulase complex (Duenas et al. 1995). Celluloses and the cellulosic components in LC substrates are essential for formation of mRNA to support maximum formation of cellulases at the transcription level (Gutierrez-Nova et al. 2003). Glucose, on the other hand, represses cellulase synthesis by a catabolite repression mechanism at the transnational level (Rajoka et al. 1998; Ponce-Noyola, 2001; Lockington et al. 2002). A study of $\beta$ cellobiohydrolase, measured on r-nitro-phenyl $\beta$-Dcellobiopyranoside and FPase, measured on filter paper (which correlated with substrate utilization parameters) by C. flavigena including its induction, repression, and production is presented.

\section{MATERIALS AND METHODS}

\section{Micro-organism and growth medium}

Cellulomonas flavigena NIAB 441 (Rajoka and Malik, 
Table 1. Specific substrate consumption rate $\left(q_{s}\right)$ specific growth rate $(\mu)$ volumetric intracelluar protein production rate $\left(Q_{\mathbb{P}}\right)$ volumetric intracellular production rate $\left(Q_{\mathbb{P}}\right)$ and $\beta$-cellbiosidae (IU/mg protein) levels in Cellulomonas flavigena strain grown on different carbon sources in Dubos medium ( $\mathrm{pH} \mathrm{7.3)} \mathrm{in} \mathrm{shake-flaks} \mathrm{batch} \mathrm{cultures} \mathrm{at} 30^{\circ} \mathrm{C}$. The values in columns have been calculated from means of three replicates; the standard deviations were $3.04 \%$ of these values and have not been presented. Values in parentheses indicate the specific activity of FPase using Whatman no. 1 filtre paper as substrate.

\begin{tabular}{|c|c|c|c|c|c|}
\hline Carbon source & $\begin{array}{c}q_{s} \\
(g / g / h)\end{array}$ & $\underset{\left(h^{-1}\right)}{\mu}$ & $\begin{array}{c}Q_{E P} \\
(m g / / / h)\end{array}$ & $\begin{array}{c}\mathrm{Q}_{\mathrm{IP}} \\
(\mathrm{mg} / \mathrm{l} / \mathrm{h})\end{array}$ & $\begin{array}{c}\beta \text {-Cellobiosidase } \\
\text { (IU/mg protein) }\end{array}$ \\
\hline Arabinose & 0.15 & 0.1 & 20.0 & 21.0 & 0.05 \\
\hline Fructose & 0.54 & 0.23 & 21.0 & 21.0 & 0.35 \\
\hline Glucose & 0.52 & 0.25 & 19.0 & 18.7 & 0.00 \\
\hline Xylose & 0.41 & 0.14 & 19.0 & 17.9 & 0.08 \\
\hline Lactose & 0.42 & 0.12 & 15.9 & 16.0 & 0.45 \\
\hline Maltose & 0.45 & 0.13 & 15.1 & 14.3 & 0.25 \\
\hline Sucrose & 0.44 & 0.12 & 14.5 & 17.3 & 0.15 \\
\hline Cellobiose & 0.52 & 0.23 & 18.1 & 14.3 & 0.55 \\
\hline Cellodextrin & 0.24 & 0.13 & 15.1 & 17.6 & $\begin{array}{c}0.85 \\
(0.84)\end{array}$ \\
\hline$\alpha$-Cellulose & 0.23 & 0.12 & 14.3 & 15.4 & $\begin{array}{c}1.33 \\
(1.31)\end{array}$ \\
\hline $\mathrm{CMC}$ & 0.21 & 0.10 & 11.5 & 11.3 & $\begin{array}{c}0.65 \\
(0.64)\end{array}$ \\
\hline Kallar grass & 0.15 & 0.12 & 14.1 & 12.1 & $\begin{array}{c}1.12 \\
(1.06)\end{array}$ \\
\hline
\end{tabular}

1997) was used in these studies. Stock cultures of the organism were stored in culture tubes using Dubos saltcellulose agar plates after the instruction of the stock culture maintainers and grown in liquid cultures as described earlier (Rajoka and Malik, 1997). All chemicals were of analytical grade. Carboxymethylcellulose (Na-salt) of low viscosity and $\alpha$-cellulose were from Sigma Chemical Co., Missouri, USA.

\section{Evaluation of carbon sources for induction of exo- glucanase}

A total of 12 different carbon sources in triplicate (Table 1) were chosen as test substrates on the basis of literature data and their availability. The organism was grown and enzyme preparations processed as described earlier (Rajoka and Malik, 1997).

\section{Effect of nitrogen sources on cellulase production}

Different nitrogen sources (Table 2) were tested to select the best nitrogen source keeping nitrogen concentration at $0.164 \mathrm{~g} / \mathrm{l}$. The cultures were grown in time course study as described earlier and processed for enzyme assays. Sodium nitrate proved to be the best nitrogen source and its concentration was optimized by changing its concentration in the medium while maintaining other optimal cultural conditions.

\section{Growth studies}

The ability of the organisms to utilize monosaccharides, disaccharides, kallar grass, with reference to cellobiose, $\mathrm{CMC}$, or $\alpha$-cellulose (Avicel) as sole carbon source was examined in basal Dubos salts medium containing $0.2 \%$ yeast extract as described earlier (Rajoka and Malik, 1997).
Carbon sources were added individually to batches of basal medium to give a saccharide level of $10 \mathrm{~g} / \mathrm{l}$. All monosaccharides and disaccharides were added to autoclaved medium after filter-sterilization. All media were adjusted to $\mathrm{pH} 7.3$ with $1 \mathrm{~mol} \mathrm{NaOH}$ or $1 \mathrm{~mol} \mathrm{HCl}$ and were dispensed in $200 \mathrm{ml}$ aliquots into 1-1 Erlenmeyer flasks in triplicate.
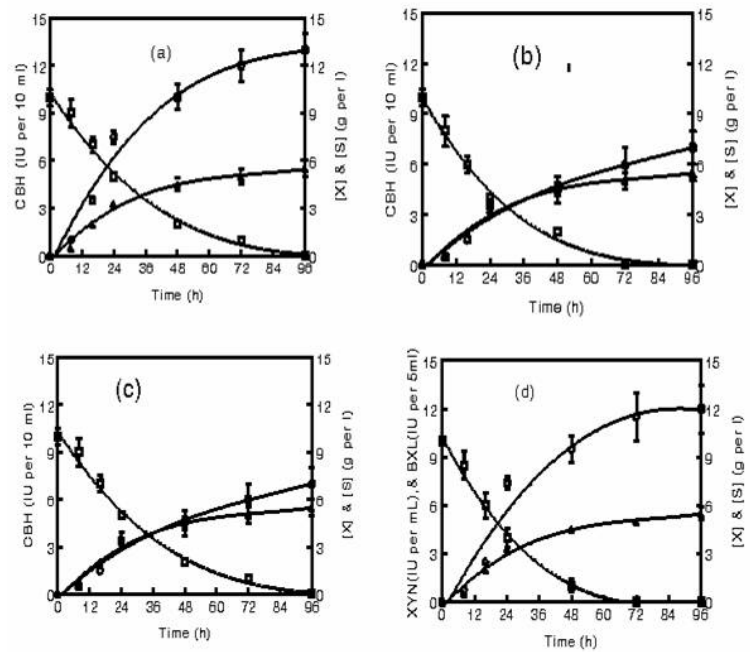

Figure 1. Kinetics of cellobiohydrolase (CBH) production in shake flask fermentation of four representative substrates. The initial $\mathrm{pH}$ of the medium was 7.3 , inoculum size $10 \%$, on $1 \%$ $(\mathrm{w} / \mathrm{v})$ carbohydrates in substrates, and temperature $30^{\circ} \mathrm{C} . \mathrm{o}=$ $\mathrm{CBH}, \Delta=$ cell mass, and $i=$ substrate present in the fermentation medium. Error bars show standard deviation among three replicates.
(a) Cellobiose;
(b) $\mathrm{CMC}$;
(c) kallar grass;
(d) Alpha-cellulose. 
Table 2. Potential substrate consumption and FPase production parameters following growth of $C$. flavigena on $\alpha$-cellulose-, CMC- or kallar grass-Dubos salts culture medium ( $\mathrm{pH}$ 7.3-7.4) in shake-flask experiments conducted at $30^{\circ} \mathrm{C}$. The organism was grown on carbon sources (containing $1 \%$ carbohydrates in basal Dubos medium. Kallar grass (Leptochloa fusca) is a salt tolerant grass grown on saline lands, (Rajoka and Malik, 1997). The values in columns have been calculated from means of three replicates; the standard deviations were $2.5-3 \%$ of these values and have not been presented. The values of $\mathrm{CBH}$ were not significantly different from those for FPase and have been omitted.

\begin{tabular}{|c|c|c|c|}
\hline \multicolumn{2}{|c|}{ Parameters } & \multicolumn{2}{|c|}{ Following growth on $1 \%$ carbohydrates in } \\
\hline & $\alpha$-cellulose & CMC & kallar grass \\
\hline $\mathrm{Y}_{\mathrm{x} / \mathrm{S}}(\mathrm{g}$ cells $/ \mathrm{g})$ & 0.550 & 0.450 & 0.540 \\
\hline$Q_{S}($ g S utized/l/h) & 0.145 & 0.135 & 0.121 \\
\hline$Q_{x}(g$ cells $/ \mathrm{l} / \mathrm{h})$ & 0.240 & 0.200 & 0.234 \\
\hline $\mathrm{Q}_{\mathrm{RS}}(\mathrm{mg} / \mathrm{l} / \mathrm{h})$ & 14.000 & 34.567 & 20.25 \\
\hline$Q_{P}(I U / / / h)$ & 35.000 & 22.00 & 32.25 \\
\hline $\begin{array}{l}\mathrm{Y}_{\mathrm{P} / \mathrm{S}}(\mathrm{IU} / \mathrm{g} \text { substrate } \\
\text { consumed) }\end{array}$ & 133.200 & 64.500 & 125.25 \\
\hline $\mathrm{Y}_{\mathrm{P} / \mathrm{X}}$ (IU/g cells) & 244.18 & 144.400 & 235.23 \\
\hline $\mathrm{q}_{\mathrm{p}}(\mathrm{IU} / \mathrm{g}$ cells $/ \mathrm{h})$ & 36.6 & 17.7 & 32.8 \\
\hline
\end{tabular}

For determining enzyme synthesis, above medium was inoculated with $10 \%$ of inoculum containing $2.5 \mathrm{~g}$ dry cells/l and incubated at $30^{\circ} \mathrm{C}$ on a rotary shaker $(150 \mathrm{rpm})$ after (Rajoka and Malik 1997). After 8, 16, 24, 48, 72, and $96 \mathrm{hrs}$ of growth, flasks in triplicate were harvested. The amount of growth was measured as dry cell mass gravimetrically. The enzyme activity present in the cell-free supernatant or cell extract was assayed as the induction or repression indicator. When the organism was grown on insoluble substrates, the whole culture medium after fermentation was centrifuged $(4000 \mathrm{~g}, 15 \mathrm{~min})$ to remove particulate substrate. The residue was shaken twice with chilled water containing $1 \%(\mathrm{v} / \mathrm{v})$ Tween 80 for $30 \mathrm{~min}$ at $4^{\circ} \mathrm{C}$ and clear supernatant was obtained by centrifugation $\left(15000 \mathrm{~g}, 30 \mathrm{~min}, 4^{\circ} \mathrm{C}\right)$. All washings were pooled for determining enzyme activities and correction was made for the adsorbed portion of FPase on the surface of the substrates. The remaining $50 \mathrm{ml}$ portion was also centrifuged (15000 g, $30 \mathrm{~min})$. The cell-free supernatant was preserved for enzyme assays and solid material was washed twice with saline, suspended in $10 \mathrm{ml}$ distilled water and dried at $70^{\circ} \mathrm{C}$ to a constant mass. Cell extract was obtained by ultra-sound disintegration and centrifugation $(15000 \mathrm{~g}, 30 \mathrm{~min})$ as described previously (Rajoka and Malik, 1997).

\section{Enzyme assay}

For cellulolytic enzyme assays, the appropriately diluted culture supernatant or cell extract (Rajoka and Malik, 1997) was used to determine FP cellulase (FPase) activity or cellobiohydrolase activity using filter paper no.1 or paranitrophenyl- $\beta$-D-cellobioside (Sigma) respectively in 0.2 mol acetate buffer $\left(\mathrm{pH} \mathrm{7)}\right.$ at $40^{\circ} \mathrm{C}$ after Nakamura and Kitamura (1988). In former tests, reducing sugars were estimated calorimetrically with 3,5-dinitrosalicylic acid method (Miller, 1959). One unit of enzyme activity is defined as the amount of enzyme, which releases one $\mu \mathrm{mol}$ of glucose equivalents or para-nitrophenol per $\mathrm{ml}$ per min respectively under the assay conditions. It was found that FPase and cellobiohydrolase from both CMC and Avicel were almost equal. Therefore, only FPase activities following growth on insoluble substrates under various conditions have been presented. While for soluble monoand di-saccharides, para-nitropheny- $\beta$-D-cellobioside was used.

\section{Saccharide determination}

Saccharides were determined using 3,5-dinitrosalicylic acid after Miller (1959). Cellulose and hemicellulose were determined as described previously (Latif et al. 1994).

\section{Protein determination}

Cellobiosidase was mainly cell-bound while FPase was secreted in the medium. Therefore, the proteins in both extracellular and cellular fractions were determined according to Bradford method (1976) using bovine serum albumin as the standard. Protein content in the substrate and spent dry matter was determined by multiplying 6.25 with nitrogen content determined by Kjeldahl's method.

\section{Determination of kinetic parameters}

Allkinetic parameters for substrate consumption and product formation (Rajoka and Malik, 1997) were determined as described previously (Rajoka et al. 1998).

\section{RESULTS AND DISCUSSION}

\section{Effect of carbon sources}

Extensive screening of potential cellobiosidase, $(\mathrm{CBH})$ or filter paperase (FPase) inducers showed that when Cellulomonas flavigena NIAB 441was cultured on media containing monomeric saccharides, dimeric saccarides, carboxy methyl cellulose (CMC), $\alpha$-cellulose or kallar grass (Table 1), it had a shorter lag period and more specific growth rate when grown on monosaccharides namely arabinose, xylose, glucose, galactose and fructose than those on disaccharides or polysaccharides, Figure 1, (Rajoka and Malik, 1997).

$\mathrm{CBH}$ was mainly present in the intracellular preparation. The organism synthesized $\mathrm{CBH}$ to a measurable level from 
Table 3. Effect of addition of glucose to $\alpha$-cellulose medium (containing $0.4 \%$ sodium nitrate in Dubos medium)on cellobiohydrolase formation parameters. Each value is a mean of three replicates. \pm stands for standard deviation among replicates. Means followed by different letters within each column differ significantly at $\rho \leq 0.05$ using one factor factorial design in MStatC software.

\begin{tabular}{|c|c|c|c|}
\hline $\begin{array}{c}\text { Glucose } \\
(\mathbf{g} / \mathbf{l})\end{array}$ & $\begin{array}{c}\mathbf{Q}_{\mathbf{p}} \\
\text { (IU/I.h) }\end{array}$ & $\begin{array}{c}\mathbf{Q}_{\mathbf{x}} \\
\text { (g cells/ I.h) }\end{array}$ & $\begin{array}{c}\mathbf{Q s}_{\mathbf{s}} \\
\text { (g substrate/ I.h) }^{\mathrm{g}}\end{array}$ \\
\hline 0.0 & $87.56 .1^{\mathrm{a}}$ & $0.430 .02^{\mathrm{c}}$ & $0.5 .10 .019^{\mathrm{a}}$ \\
\hline 1 & $79.87 .3^{\mathrm{b}}$ & $0.460 .021^{\mathrm{bc}}$ & $0.470 .023^{\mathrm{a}}$ \\
\hline 2.0 & $65.2 .56 .5^{\mathrm{c}}$ & $0.490 .023^{\mathrm{bc}}$ & $0.390 .014^{\mathrm{b}}$ \\
\hline 5.0 & $58.64 .5^{\mathrm{c}}$ & $0.490 .023^{\mathrm{bc}}$ & $0.35 .0 .017^{\mathrm{d}}$ \\
\hline 10 & $52.64 .7^{\mathrm{e}}$ & $0.570 .033^{\mathrm{a}}$ & $0.32 .0 .011^{\mathrm{c}}$ \\
\hline
\end{tabular}

disaccharides, otherwise only basal level of this enzyme was produced. Similarly FPase was produced in very small quantity below the detection limits of the assays or could not be quantified due to the presence of soluble sugars. Following growth on mono- and di-saccharides, cell extract containing cellobiohydrolase was collected and assayed for this activity. Carbon sources which supported rapid growth measured as $\mathrm{q}_{\mathrm{S}}$ (specific substrate utilization rate), $\mu\left(\mathrm{h}^{-1}\right)$ $\mathrm{Q}_{\mathrm{EP}}$ (productivity of extracellular proteins) and $\mathrm{Q}_{\mathrm{IP}}$ (productivity of intracellular proteins) were the worst repressors of enzyme synthesis. Among polymeric substrates, $\alpha$-cellulose supported the maximum activity, followed by kallar grass. Overall cellulosic substrates induced high level of enzyme activities. Among monosaccharides, only fructose synthesized cellobiohydrolase and supported the work of Nochureet al. (1993). Among disaccharides, cellobiose was the best inducer, followed by maltose and lactose. There was greater enhancement in cellobiohydrolase productivity (2.4-fold enhancement) following growth on $\alpha$-cellulose over that obtained from cellobiose (Table 1).

Additionally level of $\mathrm{CBH}$ varied over a 1.57 - to 11 -fold range with the non-inducing carbon sources namely,

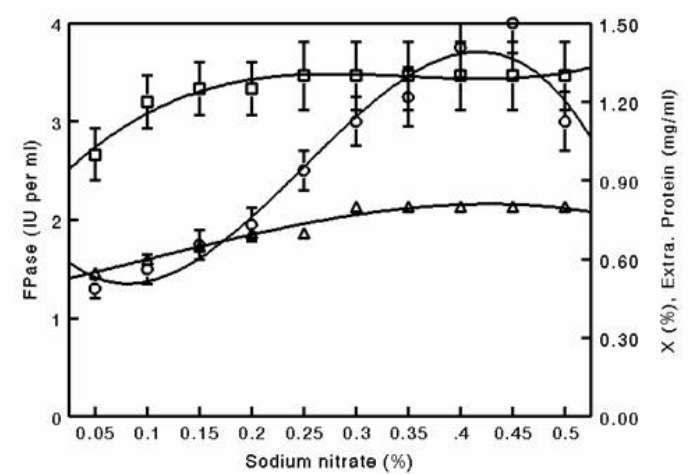

Figure 2. Effect of sodium nitrate concentration in Dubos salt medium on FPase (o), cell mass $(\Delta)$ and extracellular protein (i) production following growth on alpha-cellulose. The initial $\mathrm{pH}$ of the medium was 7.3 , inoculum size $10 \%$, on $1 \%(\mathrm{w} / \mathrm{v})$ substrate, and temperature $30^{\circ} \mathrm{C}$. Error bars show standard deviation among three replicates. xylose, arabinose, fructose and inducing carbon sources namely maltose, cellobiose, cellodextrin and cellulose (1.2to 2.38-fold) and showed inverse relationship with values of $\mathrm{q}_{\mathrm{S}}, \mu, \mathrm{Q}_{\mathrm{IP}}$ and $\mathrm{Q}_{\mathrm{EP}}$.

FPase got immobilized on cellulosic substrates (10 \pm $0.25 \%$ ) and could be successfully eluted with Tween 80 ; all values presented in different figures and tables have been compensated to include substrate-bound FPase. Similarly some cells got adsorbed on the surface of insoluble substrates. These cells contained $\mathrm{CBH}$ activity and the values of $\mathrm{CBH}$ have also been compensated to contain cellbound $\mathrm{CBH}$ activity in Table 1.

\section{Effect of nitrogen sources on cellulase production}

In $C$. flavigena, the effect of nitrogen sources was tested by replacing $\mathrm{NaNO}_{3}$ in the medium with other compounds, maintaining equi-molar amount of nitrogen at $0.164 \mathrm{~g} /$ litre. The cultures were grown for $72 \mathrm{hrs}$, harvested and processed for enzyme assays (Table 3). Inorganic nitrogen sources including $\mathrm{NH}_{4} \mathrm{Cl},\left(\mathrm{NH}_{4}\right)_{2} \mathrm{SO}_{4}, \mathrm{NH}_{4} \mathrm{H}_{2} \mathrm{PO}_{4}$ and organic nitrogen sources namely corn steep liquor and urea were the poor nitrogen sources of FPase synthesis. $\mathrm{NaNO}_{3}$, $\mathrm{KNO}_{3}$ and $\mathrm{NH}_{4} \mathrm{NO}_{3}$ were the best sources since $C$. flavigena possessed strong nitrate reductase activity which was induced by $\mathrm{NO}_{3}$ ions to an optimal level and repressed by free $\mathrm{NH}_{4}$ ions in the growth medium. Spiridonov and Wilson (1998) found that $\mathrm{NH}_{4}$ compounds are the most favourable nitrogen sources for protein and cellulase synthesis. Nakamura and Kitamura (1988) observed that polypeptone supported the maximum production of FPase and $\mathrm{CBH}$ by C. $u d a \mathrm{CB} 4$.

\section{Effect of $\mathrm{NaNO}_{3}$ on exoglucanase synthesis}

The addition of $\mathrm{NaNO}_{3}$ increased cell mass and FPase synthesis when added to the basal medium (Figure 2). FPase was secreted at elevated levels (up to 2.5-fold higher) compared with control when alpha-cellulose was used as a cellulosic substrate. However, concentrations higher than $0.45 \%$ lowered the FPase activity to some extent but it was still higher than that present in the control. The yield was two- fold that obtained in mutant derivative of $C$. biazotea (Rajoka et al. 1998). The $\mathrm{Q}_{\mathrm{p}}$ levels of FPase on alphacellulose $(87.5 \mathrm{IU} / \mathrm{l} / \mathrm{h})$ and kallar grass medium $(79.5$ $\mathrm{IU} / \mathrm{l} / \mathrm{h})$ are greater than those reported on $C$. biazotea and its mutant derivative $(18 \mathrm{IU} / \mathrm{l} / \mathrm{h}$ and $21 \mathrm{IU} / \mathrm{l} / \mathrm{h}$; Rajoka et al. 
Table 4. Effect of nitrogen sources on production of FPase, cell mass and extracellular protein production relative to control which contained $\alpha$-cellulose -Dubos salts $+0.2 \%$ yeast extract $+0.1 \%$ sodium nitrate. Control was composed of Dubos salts medium $+0.2 \%$ yeast extract and supported $35.2 \mathrm{IU} / \mathrm{l} / \mathrm{h}, 21.02 \mathrm{mg} / \mathrm{l} / \mathrm{h}$ and $0.255 \mathrm{~g}$ cells $/ \mathrm{l} / \mathrm{h}$ extracellular FPase, extracellular protein and cell mass productivity respectively. Standard deviation among 3 replicates was $2.0-3.5 \%$ of given values and have not been presented.

\begin{tabular}{|l|c|c|c|}
\hline \multicolumn{1}{|c|}{ Nitrogen } & Relative values (\%) of control \\
Cell mass & Extracelluar \\
\hline Dubos medium & & & \\
\hline Sodium nitrate in the control & 100 & 100 & 100 \\
\hline Sodium nitrate (8-fold) & 250 & 150 & 175 \\
\hline Potasium nitrate (2-fold) & 125 & 125 & 135 \\
\hline Urea & 85 & 78 & 80 \\
\hline Ammonium chloride & 30 & 25 & 35 \\
\hline Ammonium sulphate & 45 & 30 & 40 \\
\hline Diammonium hydrogen phosphate & 70 & 65 & 75 \\
\hline Sodium glutamate & 80 & 85 & 96 \\
\hline Ammonium nitrate & 90 & 95 & 80 \\
\hline Corn steep liquor & 45 & 60 & 70 \\
\hline
\end{tabular}

1998 ) and other organisms (Spiridonov and Wilson, 1998; Kalogeris et al. 2003).

During growth of the organism on different cellulosic substrates, reducing sugars accumulated (Table 4) in the growth medium as unmetabolized principles. Those substrates which released more carbohydrates were stronger repressors. The values of fermentation parameters with respect to substrate utilization, namely maximum biomass and protein productivities, $\mathrm{Q}_{\mathrm{s}}$ and $\mathrm{Y}_{\mathrm{x} / \mathrm{s}}$ from $\alpha$-cellulose, $\mathrm{CMC}$ and kallar grass (Table 2). Indicated that maximum growth in terms of dry cell biomass was significantly higher on $\alpha$-cellulose while minimum values was obtained following growth on CMC. The $\mathrm{Y}_{\mathrm{x} / \mathrm{s}}$ of $0.55 \mathrm{~g}$ cells/ $\mathrm{g}$ cellulose utilized was $98 \%$ of the maximum theoretical (0.565) of $Y_{x / s}$ from cellulose (Duenas et al. 1995). Over all, the values of all substrate consumption parameters were reasonably high. Like C. biazotea (Rajoka and Malik, 1997), C. flavigena was an active degrader of $\alpha$-cellulose and gave high values of substrate consumption parameters comparable with their corresponding amounts of $C$. biazotea on cellobiose (Rajoka and Malik, 1997).

Volumetric productivity of $\mathrm{CBH}$ and growth parameters of the organism in Dubos- $\alpha$-cellulose medium when glucose was added (1, 2.5, 5 and $10 \mathrm{~g} /$ litre final concentration) at the time of inoculation (Table 3), showed significant decrease in the enzyme synthesis. All treatments had statistically significant $(p \quad 0.05)$ influence on $\mathrm{CBH}$ productivity, substrate consumption and cell\# mass formation rates. It was found that glucose enhanced the cell mass productivity, but suppressed CBH productivity and substrate consumption rate. Mixed inductive or repressive effect has been observed in other organisms (Ponce-Noyola and De la Torre, 2001). Catabolite repression plays an important role in the regulation and secretion of inducible enzymes. Such repression effect has been also observed in other organisms (Spiridonov and Wilson, 1998; GutierrezNova et al. 2003). The effect of different glucose concentrations on $\mathrm{CBH}$ activity was determined in order to differentiate it from the effect of glucose on the synthesis of
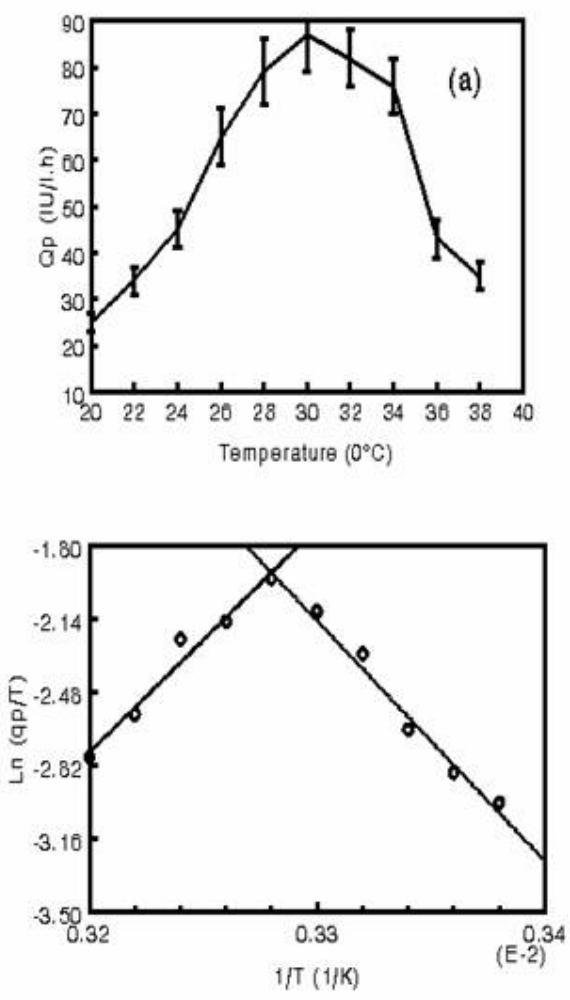

Figure 3.

(a) Effect of fermentation temperature (a) on volumetric rate of $\mathrm{CBH}$ production $\left(\mathrm{Q}_{\mathrm{P}}\right)$ following fermentation of $\alpha$-cellulose in Dubos medium. Error bars show standard deviation among three replicates.

(b) Arrhenius plot to calculate enthalpy $\left(\Delta \mathrm{H}^{*}\right)$ and entropy $\left(\Delta \mathrm{S}^{*}\right)$ of $\mathrm{CBH}$ formation and its deactivation applying relationship: $\left.\mathrm{Ln} \_\mathrm{q}_{\mathrm{p}} / \mathrm{T}\right)$ $=\operatorname{Ln}\left(k_{B} / h\right)+\Delta S^{*} / R-\Delta H^{*} / R \cdot 1 / T(\underline{\text { Table } 5})$. 
Table 5. Thermodynamic parameters estimated by Arrhenius approach for batch formation and deactivation of CBH by cultures of Cellulomonas flavigena Thermodynamic parameters were determined using following equation:

$\left.\mathrm{Ln} \_\mathrm{q}_{\mathrm{p}} / \mathrm{T}\right)=\mathrm{Ln}\left(\mathrm{k}_{\mathrm{B}} / \mathrm{h}\right)+\Delta \mathrm{S}^{*} / \mathrm{R}-\Delta \mathrm{H}^{*} / \mathrm{R} .1 / \mathrm{T}$; where $\mathrm{q}_{\mathrm{p}}, \mathrm{T}, \mathrm{k}_{\mathrm{B}}, \mathrm{h}, \Delta \mathrm{S}^{*}, \Delta \mathrm{H}^{*}$ and $\mathrm{R}$ are specific productivity, absolute temperature, Boltzmann constant, Planck's constant, entropy of activation, enthalpy of activation and gas constant respectively. The values of $k_{B}, h$, and $R$ are $1.38 \times 10^{-23} \mathrm{~J} . \mathrm{K}^{-1}, 6.63 \times 10^{-34} \mathrm{~J} . \mathrm{s}$ and $8.314 \mathrm{~J} / \mathrm{K}^{-1} \cdot \mathrm{mol}^{-1}$ respectively.

$\Delta H^{*}$ was calculated as slope and $\operatorname{Ln}\left(k_{B} / h\right)+\Delta S^{*} / R$ as intercept on $Y$-axis using Figure $2 \mathbf{b}$.

\begin{tabular}{|l|c|c|}
\hline & Enzyme formation & Thermal inactivation \\
\hline Activation enthalpy $(\mathrm{kJ} / \mathrm{mol})$ & $86.9 \pm 3^{\mathrm{b}}$ & $92.6 \pm 8^{\mathrm{a}}$ \\
\hline Activation entropy $(\mathrm{J} / \mathrm{mol} / \mathrm{K})$ & $90.5 \pm 5^{\mathrm{a}}$ & $(-) 498.5 \pm 25^{\mathrm{b}}$ \\
\hline
\end{tabular}

this enzyme; the same enzymatic activity values being obtained with these glucose concentrations studied, thus suggesting that the decrease in the content of enzyme, together with the increase in the initial concentration of glucose in the fermentation medium, was due to negative effect of sugar on the synthesis of this enzyme. Moreover, when the level of available sugar decreased as a result of culture growth, the synthesis of enzyme increased until 72 hrs of culturing. The effect of glucose was investigated with cells harvested during stationary phase in order to minimize the influence of growth. When glucose was added at the beginning of the studies, $\mathrm{CBH}$ production ceased even though the inducer (a-cellulose) was also present. However, when after $8 \mathrm{hrs}$ of incubation, the cells were washed free of glucose and placed in glucose-free medium containing acellulose, the synthesis of $\mathrm{CBH}$ started again, thus proving the reversibility of the repression mechanism of $\mathrm{CBH}$ by glucose.

\section{Effect of $\mathrm{pH}$ and temperature}

Optimum $\mathrm{pH}$ for production of $\mathrm{CBH}$ is 7.3 (results not shown). Temperatures higher than $30^{\circ} \mathrm{C}$ suppressed production of exo-glucanaseand supported the finding of Rajoka et al. (1998). Maximum specific productivity ( $\mathrm{q}_{\mathrm{P}}$ ) of $\mathrm{CBH}$ occurred at fermentation temperature of $30^{\circ} \mathrm{C}$ (Figure 3a). At higher or lower temperature, $\mathrm{CBH}$ production by the cells was low. At lower temperature, the transport of substrate across the cells is suppressed and lower yield of products are attained. At higher temperature, the maintenance energy requirement for cellular growth is high due to thermal denaturation of enzymes of the metabolic pathway (Aiba et al. 1973) resulting in minimum amount of product formation.

Effect of temperature was shown by calculating activation enthalpy of CBH production graphically from Figure $3 \mathrm{~b}$ by the application of Arrhenius approach (Aiba et al. 1973). The values of the activation enthalpy (Table 5) of $\mathrm{CBH}$ production $\left(\Delta \mathrm{H}^{*}=86.9 \mathrm{k} \mathrm{J} / \mathrm{mol}\right)$ are lower than that for glucose isomerase production reported by Converti and Del Borghi (1997). The phenomena responsible for thermal inactivation of enzyme is characterized by an activation enthalpy of $\Delta \mathrm{H}_{\mathrm{D}}{ }^{*}=92.6 \mathrm{k} \mathrm{J} / \mathrm{mol}$ and is comparable with that for $\mathrm{CBH}$ production. This suggests that the productivities decline observed at high temperature could be due to the reversible denaturation of enzyme formed on Avicel medium. The activation entropy of CBH formation $(0.095 \mathrm{k}$ $\mathrm{J} / \mathrm{mol} \mathrm{K}$ ) compares favourably with that of phytase formation (Converti and Dominguez, 2001). The activation entropy value of thermal inactivation $(-0.498 \mathrm{~kJ} / \mathrm{mol}$. K) was also very low and had negative symbols which suggested that this inactivation phenomenon implied a little randomness/disorderness during the activated state formation and compared favourably with that of $\beta$-galactosidase formation (Rajoka et al. 2003). They further led to suggest that the phenomenon limiting $\mathrm{CHB}$ production could be enzymatic reaction/s under varying fermentation conditions as observed for other enzymes (Converti and Dominguez, 2001).

\section{CONCLUDING REMARKS}

These studies led us to conclude that the carbohydrate and nitrogen sources play a vital role in the production of $\mathrm{CBH}$ or FPase by Cellulomonas. a-Cellulose was the best carbon followed by kallar grass but the former is an expensive substrate, therefore, kallar grass could be used for massl production of cellulases. In these studies, efforts were made to increase the enzyme production by manipulating above aspects only. The scope to increase the production by the use of genetical, biochemical and microbial engineering techniques to make use of full potential of this organism are to be studied. Gamma ray mutation followed by chemical mutagenesis have given mutant derivatives for improved cellulolysis (Gadgil et al. 1995; Rajoka et al. 1998) and will be used in further studies. Thermodynamic studies suggested that cells needed lower thermal energy for product formation and that the cell system exerted defence against thermal inactivation.

\section{REFERENCES}

AIBA, S.; HUMPHREY, A.E. and MILLIS, N.F. Kinetics. In: Biochemical Engineering. $2^{\text {nd }}$ Edition, New York, Academic Press, 1973, p. 92-127. 
BAHKALI, A.H. Influence of various carbohydrates on xylanase production by Verticillium tricopus. Bioresource Technology, March 1996, vol. 53, no. 3, p. 265-268.

BRADFORD, M.M. A rapid method for the quantitation of rogram quantities of protein utilizing the principle of protein-dye binding. Analytical Biochemistry. May 1976, vol. 72 , no. 1-2, p. 248-254.

CONVERTI, A. and DOMINGUEZ, J.M. Influence of temperature and $\mathrm{pH}$ on xylitol production from xylose by Debarryomyces hansenii. Biotechnology and Bioengineering, January 2001, vol. 75, no. 1, p. 39-45.

CONVERTI, A. and DEL BORGHI, M. Simultaneous effects of immobilization and substrate protection on the thermodynamics of glucose isomerase activity and inactivation. Enzyme and Microbial Technology, July 1997, vol. 21, no. 7, p. 511-517.

DUENAS, R.; TENGERDY, R.P. and GUTIERREZCOREA, M. Cellulase production by mixed fungi in solidsubstrate fermentation of bagasse. World Journal of Microbiology and Biotechnology, May 1995, vol. 11, no. 3, p. 333-337.

GADGIL, N.J.; DAGINAWALA, H.F.; CHAKRABARTI, T. and KHANNA, P. Enhanced cellulase production by a mutant of Trichoderma reesei. Enzyme and Microbial Technology, October 1995, vol. 17, no. 10, p. 942-946.

GUTIERREZ-NOVA, N.; HERRERA-HERREARA, A.; MAYORGA-YEYES, L.; SALGADO, L.M. and PONCENOYOLA, T. Expression and characterization of the celcfIB gene from Cellulomonas flavigena encoding an endo-beta-1, 4- glucanase. Current Microbiology, November 2003, vol. 47, no. 5, p. 359-363.

HAYWARD, T.K.; HAMILTON, J.; THOLUDUR, A. and MC MILLAN, J.D. Improvements in titre, productivity, and yield using solka-floc for cellulase production. Applied Biochemeistry and Biotechnolology, 2000, vol. 84-86, no. $1-9$, p. 859-874.

HOSHINO, E.; SHIROISHI, M.; AMANO, Y.; NOMURA, $M$. and KANDA, T. Synergistic actions of exo-type cellulases in the hydrolysis of cellulose with different crystallinities. Journal of Fermentation and Bioengineering,April 1997, vol. 84, no. 4, p. 300-306.

KALOGERIS, E.; INIOTAKI, F.; TOPAKAS, E.; CHRISTAKOPOULOS, P.; KEKOS, D. and MACRIS, B.J. Performance of an intermittent agitation rotating drum type bioreactor for solid-state fermentation of wheat straw. Bioresource Technology, February 2003, vol. 86, no. 3, p. 207-213.

KUBICEK, C.P.; MESSNER, R.; GUBER, F.; MACH, R.L. and KUBICEK-PRANZ, E.M. The Trichoderma cellulase regulatory puzzle: From the interior life of a secretory fungus. Enzyme Microbial Technology, February 1993, vol. 15 , no. 2 , p. $90-99$.

LATIF, F.; RAJOKA, M.I. and MALIK, K.A. Saccharification of Leptochloa fusca (kallar grass straw) by thermostable cellulases.Bioresource Technology, 1994. vol. 50, no. 2, p. 107-111.

LOCKINGTON, R.A.; RODBOURN, L.; BARNETT, S.; CARTER, C.J. and KELLY, J.M. Regulation by carbon and nitrogen sources of a family of cellulases in Aspergillus nidulans. Fungal Genetics and Biology, November 2002, vol. 37, no. 2, p. 190-196.

LYND, L.R.; WEIMER, P.J.; VAN ZYL, W.H. and PRETORIUS, I.S. Microbial cellulose utilization: fundamentals and biotechnology. Microbiology and Molecular Biology Reviews, September 2002, vol. 66, no. 3, p. 506-577.

MAGNELLI, P. and FORCHIASSIN, F. Regulation of the cellulase complex production by Saccobolus saccoboloides: Induction and repression by carbohydrates. Mycologia, 1999, vol. 91, no. 2, p. 359-364.

MILLER, G.L. Use of dinitrosalisylic acid (DNS) for determination of reducing sugars. Anal Chemistry, March 1959, vol. 31, no. 3, p. 426-428.

NAKAMURA, K. and KITAMURA, K. Cellulases of Cellulomonas uda. Methods in Enzymology, January 1988, vol. 160, no. 1, p. 211-216.

NOCHURE, S.V.; ROBERTS, M.F. and DEMAIN, A.L. True cellulase production by Clostridium thermocellum grown on different carbon sources. Biotechnology Letter,June 1993, vol. 15, no. 6, p. 641-646.

PONCE-NOYOLA, T. and DE LA TORRE, M. Regulation of cellulases and xylanases from a mutant of Cellulomonas flavigena growing on sugar-cane bagasse in continuous culture. Bioresource Technology, July 2001, vol. 78, no. 3, p. 285-291.

RAJOKA, M.I.; KHAN, S. and SHAHID, R. Kinetics and regulation of the production of $\beta$-galactosidase from Kluyveromyces marxianus grown on different substrates. Food Technology and Biotechnology, 2003, vol. 41, no. 4, p. 315-320.

RAJOKA, M.I.; BASHIR, A.; HUSSAIN, M.R.A. and MALIK, K.A. Mutagenesis of Cellulomonas biazotea for improved production of cellulases. Folia Microbiologica,January 1998, vol.43, no. 1, p.15-22.

RAJOKA, M.I. and MALIK, K.A. Cellulase production by Cellulomonas biazotea cultured in media containing different cellulosic substrates. Bioresource Technology, 
Rajoka, M. I.

January 1997, vol. 59, no. 1, p. 21-27.

SHIN, C.S.; LEE, J.P.; LEE, J.S. and PARK, S.C. Enzyme production of Trichoderma reesei Rut C-30 on various lignocellulosic substrates. Applied Biochemistry and Biotechnology, April 2000, vol. 84-86, no. 1-9, p. 237-245.

SPIRIDONOV, N.A. and WILSON, D.B. Regulation of biosynthesis of individual cellulases in Thermomonospora fusca. Journal of Bacteriology, July 1998, vol. 180 no. 4, p. 3529-3532. 